\title{
Company life cycle models and business valuation
}

\author{
Stef Hinfelaar, Michael Corbey, Frans de Roon
}

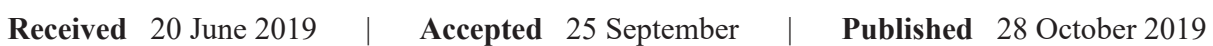

\begin{abstract}
Future free cash flow is a crucial element of most business valuation tools, such as the Discounted Cash Flow model, with the quality of the valuation depending heavily on its forecast accuracy. This paper explores the theory on business life cycle (and growth) models in an aim to improve that quality. Life cycle and growth models have been studied in the management and organization literature for decades, but the relevant aspects from a business valuation perspective remain unclear. Reviewing the existing literature, we argue that the five-stage Hanks model (Start-up, Growth, Maturity, Diversification, and Decline) is applicable for valuation purposes. We further argue that life cycle thinking provides useful insights for making grounded assumptions in predicting the future free cash flows and residual value of a company. This paper presents practical valuation approaches and insights for each of the five stages of the Hanks model.
\end{abstract}

\section{Practical relevance}

Discounted Cash Flow is a common valuation method that relies on difficult-to-make estimations of future Free Cash Flow (FCF) and Residual Value (RV). We argue that practitioners may benefit from including business life cycle modeling in assessing the expected FCF and RV to improve the quality of their valuations.

\section{Keywords}

Business Valuation, Life Cycle Models, Growth Models, Forecasting, Discounted Cash Flow, Free Cash Flow, Residual Value

\section{Introduction}

Cash that is not retained or reinvested in a company is known as free cash flow (FCF). Business valuation models such as Discounted Cash Flow (DCF) are based upon a company's expected future FCFs, but forecasting these can be difficult in practice for several reasons. First and foremost, one has to determine the forecast horizon, which is often set (rather arbitrarily) to between three and ten years. Second, the FCFs during that horizon must be forecasted. And third, one has to estimate the residual value (RV) of the business at the end of the forecast horizon. The most prevalent problem is that the uncertainty of the cash flow projections increases for each year in the forecast.

One key issue is that the characteristics of a company can change over time, and this impacts FCFs. The dyna- mics of company characteristics have been studied extensively in the management and organization literature, typically in the area of growth and life cycle models. This paper explores the relationship between the theory on growth and life cycle models and that on FCF. The general idea is that practitioners may benefit from using these models in assessing future FCFs, including in estimating the RV of a firm.

The remainder of this paper is organized as follows. The literature on growth and life cycle models is explored in Section 2. This leads to the presentation of a model that seems most suited to the business valuation setting. Subsequently, in Section 3, the link between this life cycle model and future FCF is established. The impact of 
stage transitions on FCF is discussed in Section 4, and $\mathrm{RV}$ issues are introduced in Section 5. Relationships between particular lifetime stages and FCF and RV are subsequently dealt with in Sections 6 and 7. The paper ends with conclusions in Section 8.

\section{The life cycle of a company}

Levie and Lichtenstein (2010) argue in their literature review on growth and life cycle models that a distinction can be made between models based on "sequential" (organic) versus "dynamic" states. The first approach assumes logical successive phases, while the second centers on events that bring a company to a certain 'state'. Table 1 contrasts the two approaches. It shows that organic growth models are characterized by a more predictable and predefined growth path as opposed to dynamic state models.
The majority of the models found in the literature are grounded in the organic growth model (Levie and Lichtenstein 2010). We will therefore take that as a starting point. In addition to the fact that this model is dominant in the literature, we argue that it relates to relevant and measurable business valuation aspects. Furthermore, Levie and Lichtenstein (2010) analyzed the attributes used in the models for identifying stages of growth. The mostused attributes (in the 104 models studied) were: the extent of formal systems (e.g., planning and control); the growth rate (sales, employees, etc.); the organizational structure; the characteristics of management; the formality of communication systems; the primary focus of the organization; and complexity, age, and size. These attributes were found in 35-50\% of the models. Levie and Lichtenstein (2010) coded all the attributes as elements of corresponding categories. Their results are shown in Figure 1, where the categories Outcomes (age, size, and

Table 1. Assumptions and propositions of Stages of Growth and Dynamic State models (Levie and Lichtenstein 2010).

\begin{tabular}{l|c|c}
\hline \multirow{2}{*}{ Assumption } & Organizations grow as if they were organisms & $\begin{array}{c}\text { Dach state represents management's attempts to most efficiently/effectively } \\
\text { match internal organizing capacity with the external market/customer } \\
\text { demand }\end{array}$ \\
\hline Propositions & A specific number of progressive stages & Any number of states \\
\cline { 2 - 3 } & Sequence and order are predictable & Sequence and order may be predictable depending on context \\
\cline { 2 - 3 } & Immanent program of development & Adaptive process of retaining the sustainability of a business model \\
\cline { 2 - 3 } & Prefigured rules of development & Interdependent rules for development \\
\cline { 2 - 3 } & 'Regulated' by environment & Driven by market change and opportunity creation \\
\hline
\end{tabular}

growth) and Management Characteristics (owner involvement, nature of top management, managerial style, etc.) are present in over $65 \%$ of the models.

Another finding of Levie and Lichtenstein (2010) is the repartition of the number of stages described in the different models: there is no consensus about the number of distinct stages (see Figure 2). In general, the key difference between models of four (or fewer) and five (or more) stages is that the latter include a decline phase.

All these models are largely theoretical conceptual models, and in general, there is no "hard" empirical proof of the existence of the proposed phases (Levie and Lichtenstein 2010; McMahon 1998; Solli-Sæther and Gottschalk 2010). While some studies do take an empirical approach, including Hanks (1990), Hanks and McCarrey (1993), Hanks et al. (1994), Kazanjian (1988), Kazanjian and Drazin (1989, 1990), and Miller and Friesen (1984), all of them conclude that validation is problematic.

Hanks et al. (1994) compared ten well-known life cycle models and concluded that seven dimensions were particularly relevant when it comes to identifying the five different stages:
Figure 1. Most common categories in stage models (Levie and Lichtenstein 2010).

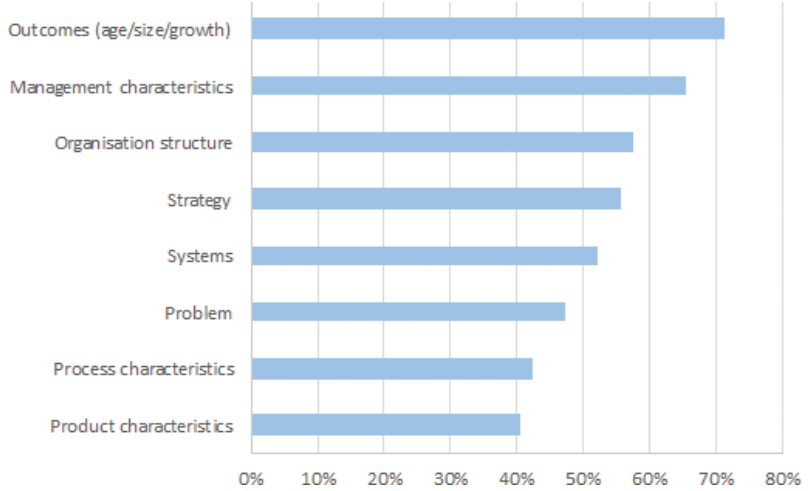

Figure 2. Number of stages in general stage models, 1962-2006 (Levie and Lichtenstein 2010).

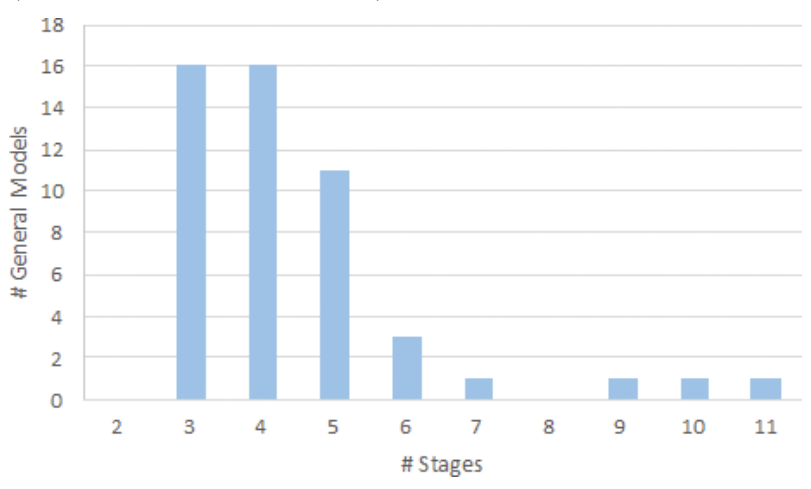


Table 2. Characteristics of company life cycle stages (Hanks et al. 1994).

\begin{tabular}{|c|c|c|c|c|c|}
\hline Dimension & Start-up stage & Expansion stage & $\begin{array}{c}\text { Maturity/consolidation } \\
\text { stage }\end{array}$ & Diversification stage & Decline stage \\
\hline Age & \multicolumn{3}{|c|}{ Young } & Older & Any age \\
\hline Size & \multicolumn{2}{|c|}{ Small } & Large & Larger & Declining \\
\hline Growth rate & Inconsistent & Rapid positive & Slow growth & $\begin{array}{c}\text { Slow growth, but } \\
\text { acceleration possible }\end{array}$ & Declining \\
\hline Structural form & Undifferentiated, Simple & $\begin{array}{c}\text { Departmentalized, } \\
\text { Functional }\end{array}$ & $\begin{array}{c}\text { Departmentalized, } \\
\text { Functional }\end{array}$ & Divisional & Mostly functional \\
\hline Formalization & $\begin{array}{l}\text { Very informal, Personal, } \\
\text { Flexible, Few policies }\end{array}$ & $\begin{array}{c}\text { Formal systems } \\
\text { begin to emerge, but } \\
\text { enforcement is lax }\end{array}$ & $\begin{array}{l}\text { Formal, Bureaucratic, } \\
\text { Planning \& control, } \\
\text { Systems are enforced }\end{array}$ & Formal, Bureaucratic & $\begin{array}{l}\text { Excessively } \\
\text { bureaucratic }\end{array}$ \\
\hline Centralization & $\begin{array}{l}\text { Highly centralized in } \\
\text { founder }\end{array}$ & $\begin{array}{c}\text { Centralized, Limited } \\
\text { delegation }\end{array}$ & Moderately centralized & Decentralized & Moderately centralized \\
\hline Business tasks & $\begin{array}{l}\text { Identify niche, Obtain } \\
\text { resources, Build } \\
\text { prototype, Set up task } \\
\text { structure }\end{array}$ & $\begin{array}{l}\text { Volume production \& } \\
\text { distribution, Capacity } \\
\text { expansion, Set up } \\
\text { operating systems }\end{array}$ & $\begin{array}{c}\text { Make business } \\
\text { profitable, Expense } \\
\text { control, Establish } \\
\text { management systems }\end{array}$ & $\begin{array}{c}\text { Diversification, } \\
\text { Expansion of product } \\
\text { market scope }\end{array}$ & $\begin{array}{c}\text { Revitalization, } \\
\text { Redefinition of mission } \\
\text { and strategy }\end{array}$ \\
\hline
\end{tabular}

"While there is considerable variability between models, all included some dimensions related to organization context and organization structure. Common contextual dimensions included organization age, size, growth rate, and focal tasks or challenges faced by the firm. Common structural dimensions included structural form, formalization, centralization, and vertical differentiation, the number of organization levels. Within models, stages are distinguished one from another by differences in the pattern and magnitude of these dimensions." (Hanks et al. 1994)

These findings are summarized in Table 2.

Empirically, Hanks et al. (1994) identified six stages: four Development (or Growth) stages and two Disengagement stages. Remarkably, they also found two atypical phases ("life style" and "capped growth") that could also be described as disengagement phases. These relate to companies that deliberately remain in a certain phase without wanting to develop further; they generate sufficient stable income, have sufficient scale and market penetration, and are reasonably profitable. It is important to consider these disengagement phases when valuing a company. The life style company is small, has existed for a long time ( $>10$ years), and has an average of seven employees. It is centrally managed, informal, and simply structured, has international specialization, and is often dependent on the founder. The capped growth company is larger and has also existed for more than 10 years, has about 25 employees with specialized positions, is functionally organized, and is clearly more structured and professionalized. The taxonomical findings of Hanks et al. (1994) in relationship to the existence of stages are consistent with McMahon (1998) and confirmed by the empirical findings of Lester et al. (2003). However, the latter are more specific in defining a Decline stage, with an "identifiable set of organizational activities and structures".

As stated before, life cycle models are prevalent in the management and organization literature but much less so in the valuation literature. Nevertheless, authors such as Damodaran (2010), Dickinson (2011), and Duff and Phelps (2013) have considered them in the context of business valuation. Their findings are referenced below, while the life cycle model of Hanks et al. (1994) serves as the benchmark for the remainder of the paper.

\section{Linking company life cycle to Free Cash Flow (FCF)}

Damodaran (2010) uses a five-stage model in discussing valuation issues. These elements that need to be taken into account in business valuation will change over the lifetime of a company. This is visualized in Figure 3, where the valuation elements are placed on the vertical axis and the life cycle stages on the horizontal axis.

The main difference between the model used by Damodaran (2010) and the Hanks et al. (1994) model is the Diversification phase, which Hanks refers to as the phase in which a company can grow again after a Maturity / Consolidation phase. Damodaran (2010) does not include

Table 3. Alignment between Hanks, Damodaran growth models.

Stages in the Hanks model Stages in the Damodaran model

\begin{tabular}{l|c}
\hline Start-up & Start-up, Young growth \\
\hline Expansion & Growth \\
\hline Maturity/Consolidation & Mature \\
\hline Diversification & Mature \\
\hline Decline & Decline \\
\hline
\end{tabular}

this phase in his model, but he does elaborate on the issue in his description of the Mature phase, applying Real Options Theory for when a company starts diversifying. The two approaches are contrasted in Table 3.

Dickinson (2011) introduces an approach by which she explicitly connects cash flow patterns to the life cycle model, thereby allowing her to classify the phase a company is in based on its operating, investment, and financing cash flows. In her view, "cash flows capture differences in a firm's profitability, growth, and risk, and the 
Figure 3. Valuation issues during company life cycle (Damodaran 2010)

\begin{tabular}{|c|c|c|c|c|c|}
\hline Revenues/ Earnings & Start-up & Young growth & Mature growth & Mature & $\begin{array}{c}\text { Decline } \\
\text { Earnings } \\
\text { Time }\end{array}$ \\
\hline $\begin{array}{l}\text { Revenues/Current } \\
\text { operations }\end{array}$ & $\begin{array}{l}\text { Nonexistent or } \\
\text { low revenues / } \\
\text { Negative } \\
\text { operating income }\end{array}$ & $\begin{array}{l}\text { Revenues } \\
\text { increasing / } \\
\text { Income still low or } \\
\text { negative }\end{array}$ & $\begin{array}{l}\text { Revenues in high } \\
\text { growth / } \\
\text { Operating income } \\
\text { also growing }\end{array}$ & $\begin{array}{l}\text { Revenues growth } \\
\text { slows / Operating } \\
\text { income still } \\
\text { growing }\end{array}$ & $\begin{array}{l}\text { Revenues and } \\
\text { operating income } \\
\text { growth drops off }\end{array}$ \\
\hline Operating history & None & Very limited & $\begin{array}{l}\text { Some operating } \\
\text { history }\end{array}$ & $\begin{array}{l}\text { Operating history } \\
\text { can be used in } \\
\text { valuation }\end{array}$ & $\begin{array}{l}\text { Substantial } \\
\text { operating history }\end{array}$ \\
\hline Comparable firms & None & $\begin{array}{l}\text { Some, but in } \\
\text { same age of } \\
\text { growth }\end{array}$ & $\begin{array}{l}\text { More } \\
\text { comparable, at } \\
\text { different stages }\end{array}$ & $\begin{array}{l}\text { Large numbers of } \\
\text { comparables at } \\
\text { different stages }\end{array}$ & $\begin{array}{l}\text { Declining number } \\
\text { of comparables, } \\
\text { mostly mature }\end{array}$ \\
\hline Source of value & $\begin{array}{l}\text { Entirely future } \\
\text { growth }\end{array}$ & $\begin{array}{l}\text { Mostly future } \\
\text { growth }\end{array}$ & $\begin{array}{l}\text { Portion from } \\
\text { existing assets / } \\
\text { Growth still } \\
\text { dominates }\end{array}$ & $\begin{array}{l}\text { More from } \\
\text { existing assets } \\
\text { than growth }\end{array}$ & $\begin{array}{l}\text { Entirely from } \\
\text { existing assets }\end{array}$ \\
\hline
\end{tabular}

combination of the three types of cash flows are mapped into life cycle theory to derive the life cycle classification". Table 4 shows Dickinson's mapping of the different effect of each stage on the three types of cash flow. In the Introduction phase, for example, there will be a negative cash flow (minus sign: -) due to the operating costs and necessary investments and a cash inflow (plus sign: + ) from financing.

The life cycle model used by Dickinson (2011) is similar to the Hanks model, with Dickinson introducing the Shake-out phase, which could be seen as the inverse of Hanks's Diversification phase. Dickinson (2011) asserts that cash flow patterns are a better predictor of (proxy for) the growth phase than the age or size of a company. This supports previous research by Anthony and Ramesh (1992) and Black (1998).

\section{Including stage transitions in FCF estimation}

The concept of company life cycles implies, as discussed, a transition through stages. There is a common understanding in the literature regarding the non-linearity of these transitions (see also Section 2). In other words, companies can regress in stages or skip one or more of them. This transitioning needs to be integrated into estimations of a company's FCF development. Starting with the initial/starting stage, a quantitative estimation needs to be made of the residence time in that stage; then, the next stage and residence time there needs to be predicted and the one after that and so on. In other words, what does the probable life cycle chain look like?

Little is found in the literature that specifically addresses this chain. Hanks et al. (1994) mention the age of a firm in their taxonomy study but provide no real data on residence times or the possible sequences of stages. Dickinson (2011) presents more explicit transition estimates. Using data over a five-year period, she provides indications of residence time and the probability of transitioning to another stage. These findings are summarized in Table 5.

In this table, a company is initially in one of the stages in the first column. We then see, for each row, the fraction of companies in that category that have transitioned to another stage after five years. For example, of the companies in the Introduction stage at the starting date of observation, $24 \%$ are still in that stage after five years; $28 \%$ have moved on to the Growth stage; $29 \%$ are Mature; and so forth. On the diagonal, the orange fields equal 
Table 4. Economic links to life cycle and cash flow patterns (Dickinson 2011).

\begin{tabular}{|c|c|c|c|c|c|}
\hline Cash flow & Introduction stage & Growth stage & Mature stage & Shake-out stage & Decline stage \\
\hline \multirow[t]{3}{*}{ Operating } & $\begin{array}{l}\text { Firms enter market with } \\
\text { knowledge deficit about }\end{array}$ & $\begin{array}{c}\text { Profit margins are } \\
\text { maximized during period }\end{array}$ & $\begin{array}{c}\text { Efficiency maximized } \\
\text { through increased }\end{array}$ & $\begin{array}{l}\text { Declining growth rates } \\
\text { lead to declining prices. }\end{array}$ & \multirow[t]{2}{*}{$\begin{array}{l}\text { Declining growth rates } \\
\text { lead to declining prices }\end{array}$} \\
\hline & $\begin{array}{l}\text { potential revenues and } \\
\text { costs }\end{array}$ & of greatest investment & knowledge of operations & $\begin{array}{l}\text { Routines of established } \\
\text { firms hinder competitive } \\
\text { flexibility }\end{array}$ & \\
\hline & (-) Cash Flows & (+) Cash Flows & (+) Cash Flows & (+/-) Cash Flows & (-) Cash Flows \\
\hline \multirow[t]{3}{*}{ Investing } & $\begin{array}{c}\text { Managerial optimism } \\
\text { drives investment }\end{array}$ & \multirow{2}{*}{$\begin{array}{l}\text { Firms make early large } \\
\text { investments to deter } \\
\text { entry }\end{array}$} & \multirow{2}{*}{$\begin{array}{l}\text { Obsolescence increases } \\
\text { relative to new } \\
\text { investment as firms } \\
\text { mature }\end{array}$} & \multirow[t]{2}{*}{ Void in theory } & \multirow[t]{2}{*}{$\begin{array}{l}\text { Liquidation of assets to } \\
\text { service debt }\end{array}$} \\
\hline & $\begin{array}{c}\text { Firms make early large } \\
\text { investments to deter } \\
\text { entry }\end{array}$ & & & & \\
\hline & (-) Cash Flows & (-) Cash Flows & (-) Cash Flows & (+/-) Cash Flows & (+) Cash Flows \\
\hline \multirow[t]{3}{*}{ Financing } & $\begin{array}{l}\text { Pecking order theory } \\
\text { states firms access bank } \\
\text { debt then equity }\end{array}$ & \multirow[t]{2}{*}{$\begin{array}{l}\text { Pecking order theory } \\
\text { states firms access bank } \\
\text { debt then equity }\end{array}$} & \multirow{2}{*}{$\begin{array}{c}\text { Focus shifts from } \\
\text { acquiring financing } \\
\text { to servicing debt and } \\
\text { distributing excess funds } \\
\text { to shareholders, such that } \\
\text { mature firms decrease } \\
\text { debt }\end{array}$} & \multirow[t]{2}{*}{ Void in theory } & \multirow[t]{2}{*}{$\begin{array}{c}\text { Focus on debt repayment } \\
\text { and/or renegotiation of } \\
\text { debt }\end{array}$} \\
\hline & $\begin{array}{l}\text { Growth firms increase } \\
\text { debt }\end{array}$ & & & & \\
\hline & (+) Cash Flows & (+) Cash Flows & (-) Cash Flows & (+/-) Cash Flows & (+/-) Cash Flows \\
\hline
\end{tabular}

the "non-transitions": cases where a company is still in the same stage after five years.

The table allows for the following interpretations:

- $\quad 81 \%$ of Introduction stage firms are likely to either stay in that stage or move to the Growth/Mature stage.

- $\quad 43 \%$ of Growth firms move to the Mature stage. The Mature stage firms are the most stable and if they move, they mainly transition back to the Growth stage.

- A small proportion of Shake-out (13\%) and Decline $(18 \%)$ firms remain in their initial stage, but there is strong movement to the Mature, Growth, and even Introduction stages. This could possibly be explained by an urge to change their business model.

Table 5. Transition analysis based on Dickinson (2011).

\begin{tabular}{l|c|c|c|c|c}
\hline \multicolumn{5}{c}{$\begin{array}{c}\text { Starting } \\
\text { Stage (t=0) }\end{array}$} & \multicolumn{5}{c}{ Tntroduction } & Inition to Stage at t+5 Years \\
Growth & Mature & Shake-Out & Decline \\
\hline Introduction & $24 \%$ & $28 \%$ & $29 \%$ & $8 \%$ & $11 \%$ \\
\hline Growth & $6 \%$ & $39 \%$ & $43 \%$ & $9 \%$ & $4 \%$ \\
\hline Mature & $5 \%$ & $29 \%$ & $56 \%$ & $8 \%$ & $2 \%$ \\
\hline Shake-Out & $9 \%$ & $28 \%$ & $44 \%$ & $13 \%$ & $6 \%$ \\
\hline Decline & $26 \%$ & $23 \%$ & $20 \%$ & $12 \%$ & $18 \%$ \\
\hline
\end{tabular}

Dickinson's (2011) findings have some limitations: first, the scope of a period of only five years is limited; and second, the history of the firms before $t=0$ is not considered. Her results do provide an empirical basis for the conceptual thinking of Phelps et al. (2007) and Levie and Lichtenstein (2010), which rejects the stages framework and introduces dynamic states. Despite the absence of research on life cycle transitions, the fact that they are clearly neither linear nor sequential emphasizes that practitioners should not take the logic of sequential organic growth in stages for granted.

\section{Including mortality in FCF estimation}

In the actual practice of business valuation, it is common to assume an infinite lifetime for the company in the cash flow estimation beyond the forecast horizon. Consequently, the RV will be treated as a perpetuity (going-concern) depending on the future cash flows (CFs), the growth rate $(g)$, and the cost of capital $(k)$, resulting in the equation:

$$
R V=C F_{t=n} *(1+g) /(k-g),
$$

where $n$ is the last year in the (explicit) forecast period. The relevance of estimating the RV relates to its importance as part of the total value of a company. In reality, companies have a limited life expectancy: less than 50 percent of new firms have a lifetime beyond 10 years (Morris 2009). This is supported by the findings of Dickinson (2011) and Damodaran (2010). The consequences of limited life expectancy should be considered in a company's FCF and will be explored in this section.

Morris (2009) and Damodaran (2010) studied these topics based on their own research combined with a review of other studies. Morris studied the mortality of firms and the impact of mortality and survivorship on value and concluded that the effect was material. He used scenario analysis to show that the magnitude of the value effect from mortality could range from $40 \%$ to over $200 \%$. Based on previous literature and surveys, he was able to provide an overview of expected life expectancy and the probability of dying or surviving. Damodaran (2010) included the results of studies he cited by Knaup (2005) and Knaup and Piazza (2007) on the longevity of over eight million U.S. companies from 1998 to 2005. Table 6 provides a summary of Morris's and Damodaran's findings and the other research they cited. 
Table 6. Summary of survival rates found in existing research in Morris (2009) and Damodaran (2010).

\begin{tabular}{|c|c|c|c|c|c|c|c|}
\hline \multirow[t]{2}{*}{ Author(s) } & \multicolumn{6}{|c|}{ Cumulative Survival Rate } & \multirow[t]{2}{*}{ Source of Data } \\
\hline & $1 \mathrm{Yr}$. & 2 Yrs. & 4 Yrs. & 5 Yrs. & 7 Yrs. & 10 Yrs. & \\
\hline Dunne et al. (1989)* & - & - & - & $43.4 \%$ & - & $26.3 \%$ & $\begin{array}{l}\text { U.S. Census of Manufacturers; } 219,754 \\
\text { manufacturing plants; } 1963-1982\end{array}$ \\
\hline Audretsch (1991)* & - & $77.4 \%$ & $63.1 \%$ & - & - & $35.4 \%$ & $\begin{array}{c}\text { Small Business Database; } 11,154 \text { manufacturing } \\
\text { firms; } 1976-1986\end{array}$ \\
\hline $\begin{array}{l}\text { Agarwal and Audretsch } \\
(2001)^{*}\end{array}$ & $93.6 \%$ & - & - & $66.1 \%$ & - & $48.7 \%$ & $\begin{array}{l}\text { Thomas Register of Manufacturers; 3,431 firms; } \\
\qquad 1906-1991\end{array}$ \\
\hline $\begin{array}{l}\text { Exponential model Morris } \\
(2009)^{*}\end{array}$ & $90.6 \%$ & $82.1 \%$ & $67.4 \%$ & $61.1 \%$ & - & $37.4 \%$ & $\begin{array}{l}\text { Small Business Administration; } 5.7 \text { million firms } \\
\text { in all sectors; 2003-2004 }\end{array}$ \\
\hline $\begin{array}{l}\text { Knaup }(2005)^{* *} \text { and Piazza } \\
(2008)^{* * *}\end{array}$ & $81.2 \%$ & $65.8 \%$ & $44.4 \%$ & $38.3 \%$ & $34.4 \%$ & - & $\begin{array}{l}\text { Bureau of Labor Statistics Quarterly Census of } \\
\text { Employment \& Wages; 8.9 million firms in all } \\
\text { sectors; 1998-2005 }\end{array}$ \\
\hline
\end{tabular}

* As cited in Morris (2009);

** As cited in Damadoran (2010)

As Table 6 shows, the majority of companies exit business life within the first ten years of existence, with only a minority $(26.3 \%-48.7 \%)$ surviving beyond that. Morris (2009) further cites an examination of business mortality rates, defined as exit rates due to unfavorable mortality, by Queen and Roll (1987). Their results are illustrated in Figure 4. Based on the work of both Queen and Roll (1987) and Morris (2009), we can conclude that there is a strong inverse relationship between firm size and mortality.

Morris's literature review also analyzed variables that affect survival. A summary of his findings is given in Table 7. These variables are related to dimensions of the life cycle model.

Morris (2009) emphasizes the need for incorporating the probabilities of survivorship/failure in estimating FCFs, as do Dickinson (2011) and Damodaran (2010). He integrates the concept of mortality into the estimate of the present value of a company, defining this as the present value of expected liquidation payments $(L)$ plus the present value of expected future CF plus the present value of the expected terminal value $\left(V_{N}\right)$. Thus, the formula for calculating the present value $V_{0}$ is:

$$
V_{0}=\sum_{j=1}^{N} P_{j} * q_{j} * L_{j} * \rho^{j}+\sum_{j=1}^{N} P_{j} * C F_{j} * \rho^{j}+P_{N} * V_{N} * \rho^{N},
$$

Figure 4. Exit rates for firms due to unfavorable mortality for selected size categories (Queen and Roll 1987, as cited in Morris 2009).

\section{Cumulative Exit Rates}

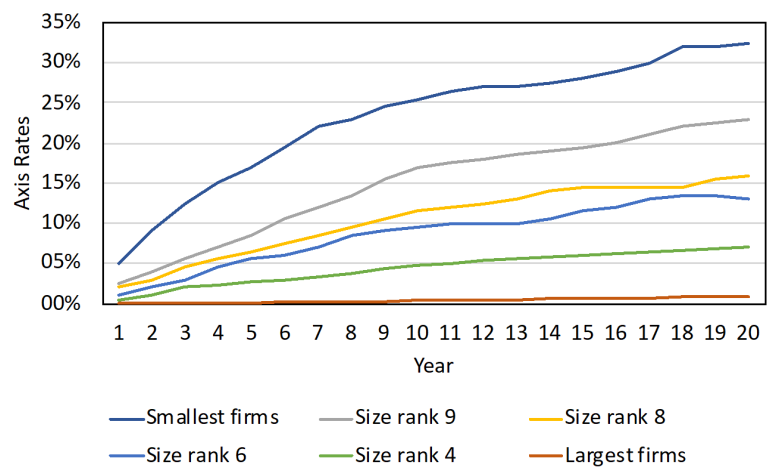

where $q_{j}$ is the probability of failure in period $j$, conditional on having survived through period $j-1$;

Table 7. Summary of literature review by Morris (2009) of variables that affect survival.

\begin{tabular}{|c|c|c|c|}
\hline & Variable & $\begin{array}{l}\text { Impact on } \\
\text { Survival }\end{array}$ & References* \\
\hline Economy & 1. Unemployment rate & - & 5 \\
\hline \multirow[t]{6}{*}{ Industry } & 2. Economy of scale & - & 4,5 \\
\hline & 3. Capital intensity & - & 4,5 \\
\hline & 4. Growth & + & 1,5 \\
\hline & 5. Profit margin & + & 4,5 \\
\hline & 6. Innovation in industry & - & 4,5 \\
\hline & 7. Industry life cycle stage & - & 1,2 \\
\hline \multirow[t]{9}{*}{ Firm } & 8. Age & + & $1,2,7$ \\
\hline & 9. Size & + & $1,2,3,4,5,6,7$ \\
\hline & 10. Liquidity & + & 3 \\
\hline & 11. Reinvestment & + & 3 \\
\hline & 12. Profitability & + & 3 \\
\hline & 13. Financial leverage & - & 3 \\
\hline & 14. Asset turnover & + & 3 \\
\hline & 15. Earnings stability & + & 3 \\
\hline & 16. Interest coverage & + & 3 \\
\hline $\begin{array}{l}* \text { References } \\
\text { as cited } \\
\text { in Morris } \\
(2009)\end{array}$ & \multicolumn{3}{|c|}{$\begin{array}{c}{ }^{1} \text { Agarwal (1997) } \\
{ }^{2} \text { Agarwal and Audretsch (2001) } \\
{ }^{3} \text { Altman (1968); Altman et al. (1997) } \\
{ }^{4} \text { Audretsch (1991) } \\
{ }^{5} \text { Audretsch and Mahmood (1995) } \\
{ }^{6} \text { Dunne et al. (1989) } \\
{ }^{7} \text { Mahmood (2000) }\end{array}$} \\
\hline
\end{tabular}

$P_{j}$ is the unconditional probability of surviving through $j$ periods; $L_{j}$ is the payoff to security holders if the firms defaults in period $j ; p^{j}$ equals $[1 /(1+k)]^{j} ; \mathrm{CF}$ is the expected cash flow in period $j$ to the security holders from the firm's normal operations when it does not fail; and $N$ is the expected residual time.

Morris (2009) simplifies this formula for situations in which a firm faces a probability of failure of $q$ for each period, with the $\mathrm{CF}$ growing at a mean rate $g$ from $\mathrm{CF}_{1}$ in period 1 , resulting in the constant growth value:

$$
V_{0}=C F_{1} *\left[\frac{1}{k-g+q+g * q}\right]
$$


This formula is like the standard perpetual growth model, but with the addition of the constant hazard of failure, $q+g * q$, to the usual denominator, $k-g$. The derivation of this equation is given in Morris (2009). As was shown in Table 6 and Figure 4, the $q$ is different at various stages of the life cycle; estimates for it are given in Morris (2009). Adjustment with $q+g \times q$ decreases value. An example of the effect of the mortality rate is given in Fi-

Figure 5. Example of value with or without mortality (Morris 2009).

Perpetuity Value With Death

(1\$, 20\% discount rate , 6\% perpetuity growth)

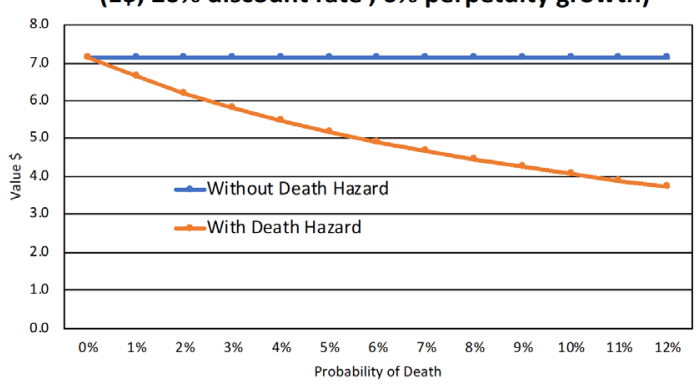

gure 5 .

In a similar way, Damodaran (2010) adds the probability of failure $\left(p_{\text {failure }}\right)$, as well as the distress sales value (liquidation value). He proposes the following formula:

$V_{\text {adapted }}=$ Value $_{\text {Going Concern }} *\left(1-p_{\text {failure }}\right)+$ Distress Sale Value $* p_{\text {failure. }}$

For practitioners, the estimation of this probability can be obtained from industry overviews, by analyzing comparable firms that survived or failed, or by using simulations. This approach of integrating the probability of mortality into future CFs requires that a choice be made in terms of either applying the approach of estimating the FCF for every year or using the shortcut of the perpetuity formula with constant growth for estimating the RV.

\section{Estimating FCF in the different life cycle stages}

\subsection{Estimating FCF in the Start-up and Young Growth stages}

In the Start-up and Young Growth stages, there is a lack of historical data and the accounting setup is often poor and non-structured. This makes it difficult to extract the operating costs versus the expenditures for the existing assets. The future CFs have to be generated by new assets, with estimation starting from almost zero due to the lack of historical data. Moreover, the Start-up stage is often split into sub-stages because of the major financial and marketing transitions involved. The first Start-up
Figure 6. Sub-stages within the Start-up stage in Damodaran (2010).

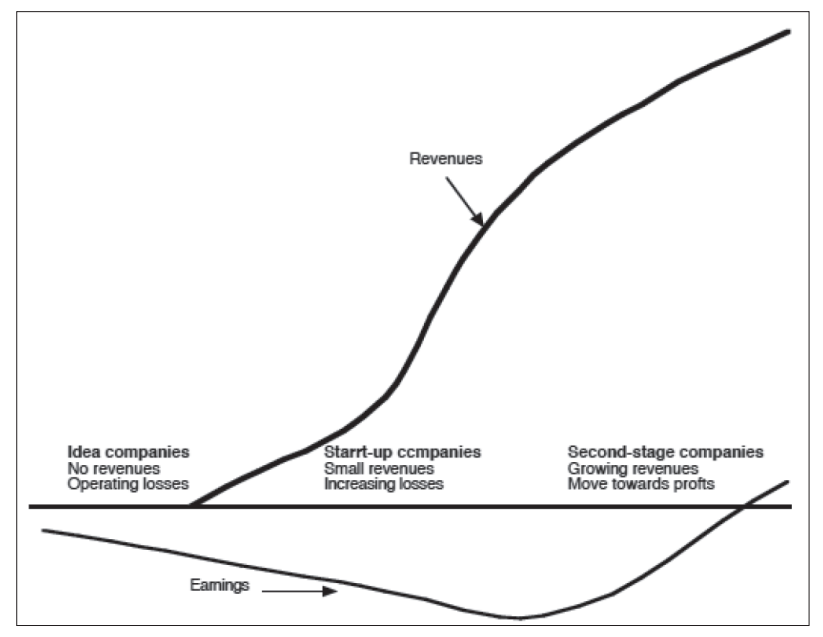

sub-stage starts with an idea or concept product, without sales and with only cash outs. The next sub-stage starts with the initial sales, though still with negative earnings while acquiring knowledge about the product and the market. The final sub-stage is when sales start to increase and positive earnings are generated (see Figure 6).

Several authors, such as Klausner and Venuto (2013) and Anshuman et al. (2012), also split the Start-up stage into sub-stages in relation to the type of investment capital needed. This is shown in Table 8 .

Damodaran (2010) suggests two approaches for estimating the FCF and combines them for cross-checking. The first is top-down: it involves estimating the total market for products/services and then deriving the top line from there based on market share and going down to operating costs/margins, needed investments for growth, and tax computing. The second is bottom-up: it builds on the business case, starting from the investments, and derives the cash flows from that.

Table 8. Sub-stages within the Start-up stage in Anshuman et al. (2012).

\begin{tabular}{l|c|c}
\multicolumn{1}{c}{$\begin{array}{c}\text { Stage of } \\
\text { development }\end{array}$} & \multicolumn{1}{c}{ Need for funding } & $\begin{array}{c}\text { Duration of } \\
\text { the investment } \\
\text { (in years) }\end{array}$ \\
$\begin{array}{l}\text { Seed and } \\
\text { Start-up }\end{array}$ & $\begin{array}{c}\text { To finance support of the } \\
\text { entrepreneur's exploration of an idea } \\
\text { up to the funding of the organization } \\
\text { of a firm that is prepared to } \\
\text { commence operations. }\end{array}$ & $\begin{array}{c}\text { More than 10 } \\
\text { First stage }\end{array}$ \\
$\begin{array}{l}\text { To fund the operations of an ongoing } \\
\text { business that is typically not yet } \\
\text { profitable. Funds are used to establish } \\
\text { initial marketing efforts and to hire } \\
\text { the necessary personnel to support the } \\
\text { anticipated growth in sales. }\end{array}$ & \\
\hline Second stage & $\begin{array}{c}\text { At this stage, the company has } \\
\text { a proven product or service and } \\
\text { funding is needed to support working } \\
\text { capital and fixed assets for growing } \\
\text { sales. }\end{array}$ & \\
\hline Bridge & $\begin{array}{c}\text { Funding is used to carry the company } \\
\text { until its initial public offering (IPO). }\end{array}$ & \\
\hline
\end{tabular}


Figure 7. Linking customer value and firm value (Gupta and Lehmann 2006).

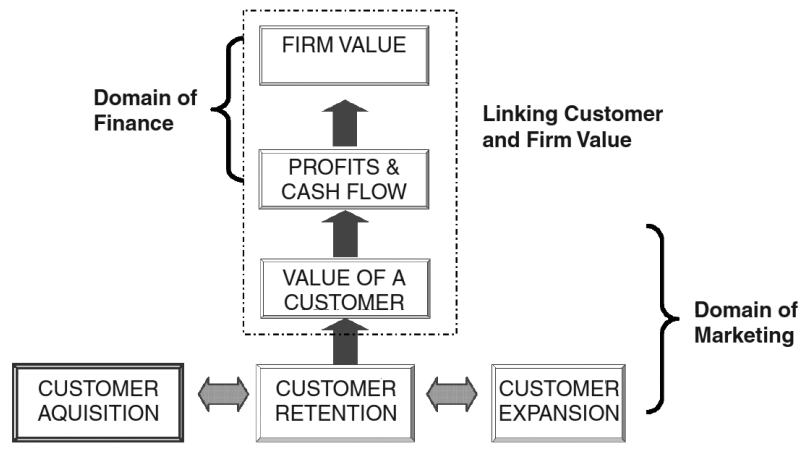

In the start-up world, measures from marketing inputs/ outputs are commonly used to build a business case (Ries 2011). In the internet world, for example, the conversion ratio of free trial to paying customers is often used in combination with customer lifetime value/cost. An example of using marketing metrics can be found in a study by Gupta and Lehmann (2006), in which they value a company (Netflix) based on the customer lifetime value. Figure 7 shows how they made this link.

This bottom-up (marketing) approach is also used for firms in the Growth stage, where a considerable portion of future value will be generated by investments in new assets. Due to the uncertainty of the future CFs, other valuation models are used in these stages, such as relative valuation and real options.

In addition to what has been described above, Damodaran (2010) points to the issue of Key Person Risk. Companies in these stages often rely on key individuals, especially in service industries. The value of the company could change if one or more of these people were no longer associated with the company. Damodaran (2010) proposes an approach to estimate this risk, defined as the Key Person Discount:

Key Person Discount $=\left(\right.$ Value $_{\text {firm status quo }}-$ Value $\left._{\text {firm key person lost }}\right) /$ Value $_{\text {firm status quo }}$ (5)

The discount rate $(k)$ for calculating the value of the status quo and the value of the key person lost are the same. Only the FCF estimation differs in the two situations.

In the literature reviewed here, studies on valuing Start-up, Early Growth, Young Growth, and High Growth companies in the high-tech environment predominate. This can be explained by its characteristics: the turbulence of the internet bubble, fascination with innovative firms, drive to find the next Google or Apple, lack of other available data, and potentially high returns.

\subsection{Estimating FCF in the Growth stage}

In the Growth stage, the main source of growing CFs is from investments in new assets, although existing assets do continue to generate CFs. When a company is aiming to invest or has already invested, its allocation of costs is often poor. This results in understating both the earnings and the value of existing assets. A feature of the Growth firm is that, over time, margins and returns change significantly. The need to address such issues as whether the upscaling and growth shown are sustainable in future years or competitors will enter the market make it more difficult to forecast future CF (Damodaran 2010).

Estimating the growth rate at this stage is the main problem: there is uncertainty about the tenability of the historical growth rate and the prediction of the future growth rate (Damodaran 2010). Dickinson (2011), Anthony and Ramesh (1992), Xu (2007), and Hanks et al. (1994) integrate sales growth per life cycle stage into their research. Damodaran (2010) provides some practical tools for assessing any assumptions regarding growth rates, such as using absolute changes instead of relative ones, considering their history, and comparing them to sector data on more mature firms in the industry. These findings are applicable for choosing the appropriate growth rate.

Another issue up for debate concerns the justification for applying the current margin or target margin and the period of change for reaching the target margin. One possible approach is to analyze the industry and make a judgment call (Damodaran 2010). Firms have to reinvest for growth, and as with the growth rate, the assumptions based on history are not always adequate. Therefore, Damodaran (2010) defines three paths for determining reinvestments. These paths depend on the characteristics of the firm. He distinguishes between growth firms early on in the life cycle, those with a more established track record of earnings and reinvestments, and those that have already invested in capacity for future years. He also provides tools for determining the reinvestment rate.

\subsection{Estimating FCF in the Mature stage}

Companies in the Mature stage mainly obtain their CF from existing assets. Valuing these assets becomes more critical than it was at earlier stages and includes considering the following issues, as outlined in Damodaran (2010). First, estimating the FCF is embedded in how such firms have used accounting rules to manage earnings and how they have covered management inefficiencies accumulated in recent years, resulting in biased returns. In addition, the revenues growth rate of Mature companies can diverge from their earnings growth rate due to improvements in operational efficiency and cost reductions. Hence, in-depth analysis of the accounting results is necessary. Finally, investing in new assets will be more focused on external growth (acquisitions) than on organic growth. In general, the value of acquisition-driven growth is much more difficult to assess than that of organic growth. Acquisitions tend to be irregular and often involve high investments, adding to the difficulty of estimating the FCF. 
Accordingly, Damodaran (2010) concludes that the main two elements required for a correct estimation of future FCF at this stage are: 1) valuing the growth from acquisitions and 2) assessing the impact of changes in the way a mature company is run. With respect to the first aspect, he suggests analyzing the historical behavior of the company with regard to acquisitions and splitting historical organic growth from external growth. Suitable tools for this include real options or decision trees, since the decisions are uncertain in time and therefore add value to the time aspect of making the decision (Copeland and Antikarov 2003). Regarding how the company is managed, Damodaran (2010) proposes more closely examining the effects of changes in operations on the business and finance strategies. Operations can change by increasing the CFs from assets in place, such as through asset redeployment, improved operating efficiency, and reduced capital maintenance and working capital investments. In addition, analyzing the possibilities of increasing expected growth and lengthening the period of high growth can result in a better forecast of expected FCF.

\subsection{Estimating FCF in the Decline stage}

At the Decline stage, two particular aspects complicate the estimation of FCFs from existing assets and their discounting in the DCF model (Damodaran 2010). First, the return on invested capital is often less than the cost of capital, resulting in a DCF that is smaller than the capital invested in the company. In such cases, logic dictates that the assets be sold or divested. That process creates discontinuities in the CFs and makes valuing more complicated. Second, declining companies derive little CF from new assets. These should therefore not have a significant effect on FCF or the value of the company. Companies in a Decline stage have to deal with negative growth (decreasing $\mathrm{CFs}$ ) and potential distress.

Damodaran (2010) offers a framework for dealing with decline and distress. This framework is presented in Table 9. The decision to divest is equivalent to the option of abandonment. Therefore, the real options approach to valuing this option can also be a way of valuing the company (Copeland and Antikarov 2003).

\section{Estimating RV in the different life cycle stages}

Having discussed the estimation of FCF per life cycle stage, we will now discuss a way to estimate RV while accommodating the characteristics/dimensions belonging to particular stages. In practice, the RV is treated as a perpetuity (going-concern) depending on the future $\mathrm{CFs}$, the growth rate $(g)$, and the cost of capital $(k)$, resulting in the equation:

$$
R V=C F_{t=n} * \frac{1+g}{k-g}
$$

In this section, we focus on the growth rate of the $\mathrm{CF}$ linked with the life cycle stage.

Beyond survivorship, the expected growth rate of CFs influences RV, while the life cycle stage defines the target growth rate. Damodaran (2010) mentions a number of issues to take into consideration. First, the growth rate has to be capped, and the effect of the growth rate on the $\mathrm{RV}$ is significant when using a rate approaching the discount rate $(k)$. Moreover, a firm cannot grow infinitely at the same (high) rate over time, whereby he argues that in the long term, the growth rate cannot exceed the economic growth rate. Damodaran (2010) suggests as a rule of thumb that the stable growth rate should not exceed the risk-free rate used in the valuation.

Stable growth firms tend to reinvest less than high growth companies. The growth rate estimation has to balance between the implied lower growth rate and the reinvestment rate for maintaining a sustainable growth rate in the terminal phase. Damodaran (2010, p. 48) concludes that "the key assumption in terminal value computation is not what growth rate you use in the valuation, but what excess returns accompany that growth rate". As a result, he proposes using the reinvestment rate in the RV (going-concern) calculation as follows:

$R V=E B I T_{n+1} *(1-t)^{*}(1-$ Reinvestment Rate $) /\left(\right.$ COC $_{n}-$ Stable Growth Rate $) .(7)$

The reinvestment rate is defined as Stable Growth Rate / Return on Capital in the stable phase.

Table 9. A framework for dealing with decline and distress (Damodaran, 2010).

\begin{tabular}{|c|c|c|}
\hline & No or low distress (little debt, investment grade rating) & High distress (high debt commitments, low ratings) \\
\hline $\begin{array}{l}\text { Irreversible } \\
\text { (sector in } \\
\text { trouble) }\end{array}$ & $\begin{array}{l}\text { Value the firm with existing management and expected } \\
\text { decline (going-concern value). } \\
\text { Value the firm assuming orderly liquidation of all its } \\
\text { assets. } \\
\text { Expected value = maximum (going-concern value, orderly } \\
\text { liquidation value ) }\end{array}$ & $\begin{array}{l}\text { Start with the expected value (irreversible, no distress). } \\
\text { Estimate the probability of distress and proceeds from forced } \\
\text { liquidation of the firm. } \\
\text { Recompute the expected value, adjusting for distress. }\end{array}$ \\
\hline $\begin{array}{l}\text { Reversible (firm } \\
\text { outlier in healthy } \\
\text { sector) }\end{array}$ & $\begin{array}{l}\text { Value the firm with existing management and expected } \\
\text { decline. } \\
\text { Value the firm with better management and recovery. } \\
\text { Expected value = status quo } \\
\text { Value } * \text { probability of no management change }+ \text { optimum } \\
\text { value } * \text { probability of management change }\end{array}$ & $\begin{array}{l}\text { Start with the expected value (reversible, no distress). } \\
\text { Estimate the probability of distress sale of the firm. } \\
\text { Recompute the expected value, adjusting for distress. } \\
\text { If equity investors run the firm, value the option to liquidate. }\end{array}$ \\
\hline
\end{tabular}


Damodaran's (2010) approach of introducing reinvestment in the RV can be traced back to the conceptual work of O'Brien (2003). In his model of valuation, which was based on Miller-Modigliani, O' Brien introduced a decay factor or rate $(d)$, defined as the fade rate at which the return on equity for new investments is expected to converge towards the firm's cost of equity $(f)$ minus the expected growth rate of incremental investments $(g)$.

\subsection{Estimating RV in the Start-up and Young Growth stages}

As discussed in section 6.1, the estimation of the FCF at this stage must address uncertainties, and therefore also assumptions based on those uncertainties. The estimation of $\mathrm{RV}$ adds further uncertainty caused by looking into the future beyond the horizon of the FCF forecast. For this stage, too, the risk of failure is important, and it is therefore preferable to apply a failure probability in estimating the FCF.

\subsection{Estimating RV in the Growth stage}

The specificity of this stage regarding RV is reflected in the question of when and how to incorporate the trans ition from a fast-growing company to a mature company with a lower growth rate (Damodaran 2010). Damodaran (2010) offers no concrete solution for this, but he shares tips from his own experience. First, he suggests not waiting too long to put a firm in stable growth, because of the impact that a high growth rate has on RV, and "both scale and competition conspire to lower growth rates quickly at even the most promising companies" (Damodaran 2010, p. 286). Second, when putting the firm into stable growth, he recommends giving it the characteristics of a stable growth firm. This influences discount rates, debt costs, equity/debt ratios, investment rates, and so on. In Damodaran's view, the impact of the probability of failure is low at this stage, and the application of the failure or mortality rate in the estimation of FCFs can be abandoned.

\subsection{Estimating the RV in the Mature stage}

RV accounts for a large share of the overall value of a Mature firm, and its estimation might seem easier than in the Growth stage, because the growth rate tends to converge to the economic growth rate. The economic growth rate is the percentage change in the value of all of the goods and services produced in a nation during a specific period of time, as compared to an earlier period. Some factors could distort the estimation, however. The first concern is the profile of the company. Although the growth rate is stable and lower than the economic growth and risk-free rate, a company in the Mature stage can have a high risk (e.g., beta $>2$ ) and needs a reinvestment level close to its total income, making the estimation of RV more complicated. Moreover, as noted in section 6.3, inefficiencies related to the running of companies in the Mature stage could also affect their RV and thus the risk of undervaluation (Damodaran 2010).

\subsection{Estimating the RV in the Decline stage}

At the Decline stage (with/without distress), the estimation of RV requires specific approaches similar to those already shared for FCF estimation in section 6.4. Here, there is a possibility that the firm may not make it to stable growth. Many distressed firms default and go out of business or liquidate. For those that achieve a steady state, the growth rate may be far below the economic growth rate and even negative. The firm continues to exist, but it becomes progressively smaller as its market share shrinks (Damodaran 2010). Damodaran (2010) incorporates the probability of distress into the RV estimation as he did with the probability of failure:

Firm Value $=$ Going concern $*\left(1-p_{\text {distress }}\right)+$ Distress value $* p$

where $p_{\text {distress }}$ is the cumulative probability of distress over the valuation period.

Despite the fact that the magnitude of the growth rate for deriving the RV is often limited, the impact of the total RV is important. The life cycle approach supports the choice for the most suitable assumptions for the RV estimation. The use of the shortcut of RV calculation as perpetuity should be skipped when integrating the probability of failure into the FCF estimation.

\section{Conclusions}

In this article, we have shown that integrating the concept of a company life cycle into the daily practice of business valuators improves the quality of the value estimation. Including life cycle models in the process of determining the value of a company provides insights for making more grounded assumptions. Life cycle thinking helps practitioners assess the risks and structurally improves prediction of future CFs. It is critical to take aspects such as mortality, expected growth rates, distress risk, and future investments explicitly into account in the valuation process. We analyzed the implications for the estimation of FCF and the RV for each stage of the life cycle and translated them into practical insights and approaches for valuation practitioners. These findings are summarized in Table 10 below.

Transitions from one stage/state to another and residence times in particular stages have not been extensively studied in the literature; Dickinson's (2011) was the only work found in this area. Yet, aspects such as estimated stage residence time and probability of passing to the next stage or state are relevant to life cycle thinking and the valuation process. In the models presented, we have broadly discussed specific elements of this thinking in terms of stage transitions within the life cycle. Further empirical research is needed to provide more insight into such time aspects (stage residence time) and would also enrich the theoretical insights into the sequence or of business lifetime stages. 
Table 10. Summary of practical insights and approaches.

\begin{tabular}{|c|c|c|}
\hline \multirow[t]{2}{*}{ Stage in Life Cycle } & \multicolumn{2}{|l|}{ Estimation of: } \\
\hline & FCF & $\mathbf{R V}$ \\
\hline $\begin{array}{l}\text { Start-up and Young } \\
\text { Growth }\end{array}$ & $\begin{array}{l}\text { Combine different sources/approaches for estimating the FCF. } \\
\text { The projections of the management are too restrictive. There is a } \\
\text { knowledge deficit, and there are often large investments. } \\
\text { Growth rates are often inconsistent. } \\
\text { Look for proven (non-financial) metrics as predictors of FCF. } \\
\text { Take into account the dependency on key persons. }\end{array}$ & Include the probability of failure. \\
\hline Growth & $\begin{array}{l}\text { Separate FCF prediction from existing assets and new assests. } \\
\text { Use comparables and literature studies for estimating the growth } \\
\text { rate. Growth is rapid and positive. } \\
\text { Good assessment of the needed reinvestment level/rate possible. }\end{array}$ & $\begin{array}{l}\text { In beginning, include the probability of failure. } \\
\text { Use stable (lower) growth rate, e.g., growth rate } \\
\text { based on reinvestment rate explained in Section } 7 .\end{array}$ \\
\hline Mature & $\begin{array}{l}\text { In-depth analyses of the accounted results to produce explicit real } \\
\text { operational versus bookkeeping results. } \\
\text { Split FCF between historical operations and acquisitions. } \\
\text { Growth rate is declining. } \\
\text { If growth depends on acquisitions, dive into historical success } \\
\text { rate of doing this. Natural growth is slow. Dive into the way the } \\
\text { company is managed for agency effects (inefficiencies). }\end{array}$ & $\begin{array}{l}\text { Growth rate often below risk-free rate and/or eco- } \\
\text { nomic growth. } \\
\text { Special attention: agency effects (inefficiencies) } \\
\text { could increase growth rate. }\end{array}$ \\
\hline Decline & $\begin{array}{l}\text { In-depth analyses of the accounted results to produce explicit real } \\
\text { operational versus bookkeeping results. } \\
\text { Assessment of the level of (potential) distress and inclusion of } \\
\text { this in the FCF prediction. } \\
\text { Split FCF between historical operations and acquisitions. } \\
\text { Growth rate is declining. }\end{array}$ & $\begin{array}{l}\text { No use of RV calculation as perpetuity. } \\
\text { Include distress or failure probability. }\end{array}$ \\
\hline
\end{tabular}

- Drs. Ing. Stef Hinfelaar MiF MBV is an alumnus of the Executive Master in Finance and the Executive Master of Business Valuation programs, TIAS School for Business and Society, Tilburg University.

- Prof. dr. ir. Michael Corbey is Full Professor of Management Accounting and Control and Academic Director of the Executive Master of Finance and Control / Register Controller programs, TIAS School for Business and Society, Tilburg University.

- Prof. dr. Frans de Roon is Full Professor of Finance and Academic Director of the Executive Master in Finance and the Executive Master of Business Valuation programs at TIAS School for Business and Society, Tilburg University.

\section{References}

- Agarwal R (1997) Survival of firms over the product life cycle. Southern Economic Journal 63 (January): 571-584. https://doi. org/10.2307/1061095

- Agarwal R, Audretsch D (2001) Does entry size matter? The impact of the life cycle and technology on firm survival. Journal of Industrial Economics 49(1): 21-43. https://doi.org/10.1111/1467-6451.00136

- Altman E (1968) Financial ratios, discriminant analysis and the prediction of corporate bankruptcy. Journal of Finance 23(4): 589-609. https://doi.org/10.1111/j.1540-6261.1968.tb00843.x

- Altman E, Haldeman R, Narayanan P (1997) Zeta ${ }^{\mathrm{TM}}$ analysis: a new model to identify bankruptcy risk in corporations. Journal of Banking and Finance 1(1): 29-54. https://doi.org/10.1016/03784266(77)90017-6

- Anshuman VR, Martin J, Titman S (2012) An entrepreneur's guide to understanding the cost of venture capital. Journal of Applied Corporate Finance 24(3): 75-83. https://doi.org/10.1111/j.17456622.2012.00391.x

- Anthony J, Ramesh K (1992) Association between accounting measures and stock prices. Journal of Accounting and Economics 15(2-3): 203-227. https://doi.org/10.1016/0165-4101(92)90018-W
- Audretsch D (1991) New firm survival and the technological regime. Regime of Economics and Statistics 73(3): 441-450. https:// doi.org/10.2307/2109568

- Audretsch D, Mahmood T (1995) New firm survival: New results using a hazard function. Review of Economics and Statistics 77(1): 97-103. https://doi.org/10.2307/2109995

- Black EL (1998) Life-cycle impacts on the incremental value-relevance of earnings and cash flow measures. Journal of Financial Statement Analysis 4(1): 40-56.

- Copeland T, Antikarov V (2003) Real options: A practitioner's guide. Cengage Learning (New York).

- Damodaran A (2010) The dark side of valuation: Valuing young, distressed, and complex business. FT Press (Upper Saddle River, New Jersey).

- Dickinson V (2011) Cash flow patterns as a proxy for firm life cycle. The Accounting Review 86(6): 1969-1994. https://oi.org/10.2308/ accr-10130

- Dunne T, Roberts M, Samuelson L (1989) The growth and failure of U.S. manufacturing plants. Quarterly Journal of Economics 104(4): 671-698. https://doi.org/10.2307/2937862 
- Duff, Phelps (2013) Risk Premium Report 2013. Duff \& Phelps, LLC. (Chicago, IL). https://www.duffandphelps.com/insights/publications/cost-of-capital/2013-duff-and-phelps-risk-premium-report

- Gupta S, Lehmann DR (2006) Customer lifetime value and firm valuation. Journal of Relationship Marketing 5(2/3): 87-110. https:// doi.org/10.1300/J366v05n02_06

- Hanks SH (1990) The organization life cycle: Integrating content and process. Small Business Strategy 1(1): 1-12. https://doi. org/10.1300/J366v05n02_06

- Hanks SH, McCarrey L (1993) Beyond survival: Reshaping entrepreneurial vison in successful growing ventures. Journal of Small Business Strategy 4(1): 1-12. https://libjournals.mtsu.edu/index. php/jsbs/article/view/264

- Hanks SH, Watson CJ, Janssen E, Chandler GN (1994) Tightening the life-cycle construct: A taxonomic study of growth stage configurations in high-technology organizations. Entrepreneurship: Theory and Practice 18(2): 5-29. https://doi. org/10.1177/104225879401800201

- Kazanjian RK (1988) Relation of dominant problems to stages of growth in technology based new ventures. Academy of Management Journal 31(2): 257-279. https://doi.org/10.5465/256548

- Kazanjian RK, Drazin R (1989) An empirical test of a stage of growth progression model. Management Science 35(12): 14891503. https://doi.org/10.1287/mnsc.35.12.1489

- Kazanjian RK, Drazin R (1990) A stage contingent model of design and growth for technology based new ventures. Journal of Business Venturing 5(3): 137-150. https://doi.org/10.1016/08839026(90)90028-R

- Klausner M, Venuto S (2013) Liquidation rights and incentive misalignment in start-up financing. Cornell Law Review 98(6): 1399 1434. https://scholarship.law.cornell.edu/cgi/viewcontent.cgi?arti$\mathrm{cle}=3283 \&$ context $=\mathrm{clr}$

- Knaup AE (2005) Survival and longevity in the business employment dynamics data. Monthly Labor Review 128(5): 50-56. http:// www.jstor.org/stable/23805521

- Knaup AE, Piazza, MC, (2007) Business employment dynamics data: survival and longevity, II. Monthly Labor Review 130(9): 3-10. http://www.jstor.org/stable/23806910
- Lester DL, Parnell JA, Carraher S (2003) Organizational life cycle: A five stage empirical scale. The International Journal of Organizational Analysis 11(4): 339-354. https://doi.org/10.1108/ eb028979

- Levie J, Lichtenstein BB (2010) A terminal assessment of stages theory: Introducing a dynamic approach to entrepreneurship. Entrepreneurship: Theory \& Practice 34(2): 317-350. https://doi. org/10.1111/j.1540-6520.2010.00377.x

- Mahmood T (2000) Survival of newly founded businesses: A log-logistic model approach. Small Business Economics 14(3): 223-237 https://doi.org/10.1023/A:1008116207175

- McMahon RG (1998) Stage models of SME growth reconsidered. Small Enterprise Research 6(2): 20-35. https://doi.org/10.5172/ ser.6.2.20

- Miller D, Friesen PH (1984) A longitudinal study of the corporate life cycle. Management Science 30(10): 1161-1183. https://doi. org/10.1287/mnsc.30.10.1161

- Morris JR (2009) Life and death of businesses: A review of research on firm mortality. Journal of Business Valuation and Economic Loss Analysis 4(1): 1-39. https://doi.org/10.2202/1932-9156.1050

- O'Brien TJ (2003) A simple and flexible DCF valuation formula. Journal of Applied Finance 13(2): 54-62. https://ssrn.com/abstract $=253448$

- Phelps R, Adams R, Bessant J (2007) Life cycles of growing organizations: A review with implications for knowledge and learning. International Journal of Management Review 9(1): 1-30. https://doi. org/10.1111/j.1468-2370.2007.00200.x

- Queen M, Roll R (1987) Firm mortality: Using market indicators to predict survival. Financial Analysts Journal 43(3): 9-26. https://doi. org/10.2469/faj.v43.n3.9

- Ries E (2011) The lean startup. Crown Business, New York.

- Solli-Sæther H, Gottschalk P (2010) The modeling process for stage models. Journal of Organizational Computing and Electronic Commerce 20(3): 279-293. https://doi.org/10.1080/10919392.201 0.494535

- Xu B (2007) Life cycle effect on the value relevance of common risk factors. Review of Accounting and Finance 6(2): 162-175. https:// doi.org/10.1108/14757700710750838 